\title{
Before the Colditz Myth: \\ Telling POW Stories in Postwar British Cinema
}

\author{
Gill Plain
}

Gill Plain is Professor of English Literature and Popular Culture at the University of St Andrews. Her research interests cover twentieth-century war writing, crime fiction, British cinema and gender studies, and her publications include Women's Fiction of the Second World War (1996), Twentieth-Century Crime Fiction: Gender, Sexuality and the Body (2001), John Mills and British Cinema: Masculinity, Identity and Nation (2006) and Literature of the 1940s: War, Postwar and 'Peace' (2013).

\begin{abstract}
Before the concretization of the 'Colditz Myth' in the mid-1950s, British cinema's engagement with the POW narrative took unexpected generic forms. The Captive Heart (1946) and The Wooden Horse (1950) draw on the narrative conventions and structures of feeling mobilized by documentary realism, romance, melodrama and crime. Exploring these films as hybrid genres draws attention to their capacity to symbolize a range of postwar social anxieties, in particular regarding demobilisation, repatriation and the reconstruction of peacetime masculinities. The films depict the frustration and boredom of incarceration, and build narratives of reassurance out of group and individual coping strategies. Yet, while characters might escape, the 'duty to escape' is not a central preoccupation: rather the films focus on the relationship between camp and home, and the
\end{abstract}


reconstruction of the incarcerated male subject. Between 1946 and 1955, cinema variously imagines the prisoner of war camp as a space of holistic reconstruction, and as a site for the reconstruction of male agency through productive labour. These films, then, bear little resemblance to the war genre through which they are usually conceptualised: rather they draw on domestic tropes to examine the pressures confronting the male subject in the aftermath of war.

\section{Keywords}

British Cinema; Masculinity; Genre; War films; structures of feeling; home; demobilization.

... the Colditz Story was central in creating an enduring set of popular assumptions in which life behind the wire was interpreted, both figuratively and sometimes literally, in sporting terms. Escape was the name of the game, with the team from Oflag IVC topping the league tables in terms of home runs. The popular image of what went on at Colditz castle ... became and remained one in which prisoners bore the burden of captivity with a light heart while helping one another with schemes to outwit and ultimately evade their captors (MacKenzie, 2004: 1-2).

It is the constant hope of nearly every prisoner-of-war - if not, indeed, his duty to escape and rejoin his unit (The Wooden Horse, 1950). 
The Colditz Myth, and the 'duty to escape' that it enshrines, forms the dominant narrative paradigm through which POW experience in the European theatre of war is known. Irrespective of the actual experiences of the bulk of British POWs, in the aftermath of war, the business of surviving incarceration comes increasingly to be written, and filmed, as a narrative of resistance undertaken by officers. The appeal of this story to the collective imagination is not hard to understand, mobilizing as it does the nostalgic mythologization of the Second World War as the triumph of the underdog, a narrative of creative iconoclasm pitted against the humourless mechanized force of Fascism. Yet when hostilities ceased, there was little immediate appetite for war films, and the first POW stories to be told took quite different forms: indeed, arguably the earliest example is Frank Launder's irreverent drama about a women's internment camp, Two Thousand Women (1944). This was followed in 1946 by The Captive Heart, a self-proclaimed endof-war tribute to the 'forgotten men' of the conflict, and then, after a four-year gap, The Wooden Horse (1950). The film was based on Eric Williams' successful 1949 novel, described by Ken Worpole as one of the most 'detailed and convincing' of all World War Two escape stories (1983: 53). Worpole observes that The Wooden Horse was marketed as part of a 'popular literature of male adventure' (1983: 54), but - like The Captive Heart before it - the story might equally be seen as the antithesis of adventure, or even of war. Bruce Babington situates Two Thousand Women at the centre of its director's 'home front trilogy' (2002: 65-68), and this should give us pause for thought in examining the structure of the male POW narrative. Before the Colditz myth took hold, POW films focused on the experience of a homosocial group enclosed within a domestic framework 
of stasis, boredom, hunger and frustration. They were stories of masculinity under stress, and carried with them not so much the duty of escape, but the fear of what lies beyond freedom: home, rehabilitation and readjustment. The Captive Heart and The Wooden Horse, as I hope to demonstrate, are only superficially accounts of incarceration and escape: rather, at the core of both films lies an anxious examination of the pressures confronting the male subject in the aftermath of war.

That the Colditz myth, like all myths, was a selective representation is evident from historical accounts of POW experience. In the work of David Rolf and Adrian Gilbert, the 'duty to escape' emerges as at best an ambivalent imperative, and at worst a positive liability. While some POWs found the activity of escape planning psychologically beneficial - it was, suggests Adrian Gilbert, 'an antidote to the boredom of everyday camp life' (2006: 262) - many were uncomfortable with the disruptive activities, escape attempts and 'goon-baiting' that, while arguably creating problems for the Germans, often served only to bring further hardship and reprisals on the bulk of the community (Rolf, 1988: 135-6; Gilbert, 2006: 266, 278). Indeed, for many prisoners it was reading that became the preferred mode of escape, and an appetite - even a 'compulsion' - for books crossed the divides of class and education (Gilbert, 2006: 1823). ${ }^{1}$ The virtual escape represented by reading ironically links the prisoner of war to the nation from which he is exiled. This is not to underestimate the considerable hardship suffered by many POWs - they were undoubtedly more constrained, more hungry and more vulnerable than the bulk of the home front population - but it is to observe a shared desiccation of experience that lies behind Christine Geraghty's suggestive observation 
that 'one of the attractions of the POW films may have been that, despite their specific setting, they offer an account of wartime experiences that were not confined to those who had been captured' (2000: 199). In other words, the boredom, the bureaucracy, the shortages, the vulnerability to attack and the enforced passivity of perpetual waiting spoke not only to the experience of captivity, but also to the wartime experiences of military service and the civilian war economy.

The flexible interpretative possibilities embedded within incarceration stories made before the myth speaks eloquently to the uncertainties surrounding the politics and representation of reconstruction. Cinema in the second half of the 1940s underwent a series of shifts, as the taste for documentary realism and representations of war was replaced at the box office by narratives that seemed more effectively to metaphorize the psychic anxieties of a traumatized and exhausted nation. As critics such as Alison Light, Jeffrey Richards and Lynne Segal have demonstrated, British mid-century culture, especially in its middle-class variants, did not facilitate the open expression of emotion (Light, 1991: 108; Richards, 1997: 87-8, 125; Segal, 1990/1997: 5). Furthermore, the 'expressive culture' of Britain offered no language for the articulation of loss or grief and, in a culture that wanted to restore 'the rhythms of everyday life' to how they had been 'before the war', there would have been little space in which to speak this pain (Kynaston, 2007: 80). ${ }^{2}$ Neither the war, nor the wounds it had left, were welcome. Consequently, in place of the direct representation of wartime suffering, and of the difficulties of returning to 'peace' experienced by both men and women, British cinema offered genres that spoke to the unspeakable. Through the formulae of romantic 
melodrama and crime, violence, passion, pleasure, resentment and frustration found expression on the screen.

Marcia Landy argues that popular cinema genres are integral to the shaping of cultural attitudes; they do not merely reflect socio-political issues, they 'offer significant clues to tensions and contradictions in relation to such issues as historicism, notions of community, gender, social class, and sexuality' (1991: 13). Sue Harper and Vincent Porter agree, suggesting that genres, by facilitating the expression and containment of cultural anxieties, serve a 'crucial social function' (2003: 269). Harper and Porter also observe the reactive quality of genres and the 'volatile' nature of their production and consumption. The 'structures of feeling' evident in popular genres, they argue, change 'every two or three years, along with the fluctuating moods and emotional responses of the cinema-going public' (1983: 248). A brief mapping of cinema trends across the war and postwar period demonstrates this volatility. The first significant trend to emerge in response to wartime pressures and conditions of production was a homegrown film product that mobilized a documentary realist aesthetic and consciously strove to represent ordinary people on the screen. In films such as The Foreman Went to France (1942), Millions Like Us (1943) and The Way Ahead (1944), the individual imperial hero of the 1930s was replaced by inclusive constructions of regionally-diverse, cross-class (and cross-gender) group heroism. Yet as the war progressed, and the immediate threat of invasion was replaced by a seemingly interminable wait for the end, audiences tired of war films. As boredom and exhaustion replaced fear, the need for distraction was met by the resurgence of melodrama. From The Man in Grey (1943) to The Wicked Lady (1945), 
many of the box office successes of the mid-1940s were lurid historical romances featuring Byronic heroes and wilful women, and a mise-en-scène far removed from the drab constraints of austerity. As the decade progressed, the fluctuating mood of the nation also found expression in the emergence of the so-called 'spiv cycle', a series of dark, expressionistic crime films that spoke to the uncertainties surrounding demobilization and reconstruction. The sub-genre is usually considered to have started with Waterloo Road (1945), in which a soldier goes AWOL to rescue his wife from a predatory spiv, but later examples such as They Made Me a Fugitive (1947) and It Always Rains on Sundays (1947) more fully articulate the threat of the returning combatant. In the first of these, a pathologically bored former RAF pilot is recruited into the world of black market smuggling; in the second, the ex-combatant is figured as an escaped prisoner, returning to an old lover and fracturing the delicate equilibrium of her prosaic home life.

In the early 1950s, though, dominant structures of feeling shifted again, and the war film returned to favour, albeit in a more conventional form focused upon the resurgence of middle-class individual agency. In Christine Geraghty's words, in the 1940s, 'the war was fought by whole communities, including the working class, women and civilians, but the fifties war film tends to place an emphasis on a small male group, largely made up of officers and "boffins"” (2000: 181). Films such as The Dam Busters (1955) and Reach for the Sky (1956) reinstate the inspired individual, a leader of men set apart from the group, and the ideological work performed by these stories is significantly different from the consensus building at the heart of earlier films. Neil Rattigan configures the transition in terms of class anxiety, arguing that popular 1950s war cinema 
represents a 'last ditch effort by the dominant class to maintain its hegemony by rewriting the history of the celluloid war in its own favour' (1994: 150). Michael Paris, by contrast, reads the transformation in terms of broader political anxieties:

As Britain struggled to re-assert her position as a world leader in an age dominated by the Superpowers, representations of the war of the common man gave way to representations of an elite leadership paving the way to victory (Paris, 2007: 3).

Somewhat ironically, the war of the common man also mutated into representations of the British hero as fool, rogue and innocent abroad, as comedy emerged as the other dominant genre of the 1950s. This would have significant implications for the POW narrative, as its dominant exemplar - The Colditz Story (1955) - depended heavily on the violent irreverence of comedy for its impact (Harper and Porter, 2003: 268). Pat Reid's phenomenally successful books, The Colditz Story (1952) and The Latter Days at Colditz (1953), rely on humour as a means of negotiating unbearable circumstances. In the first book in particular, the spirit of adventure is prioritized over the trauma of incarceration; suffering is displaced through banter, agency is restored through schoolboy pranks (Reid, 2003: 106). ${ }^{3}$ The film, directed by Guy Hamilton, followed Reid's lead, making comedy an integral part of a drama that was part adventure and part school story (MacKenzie, 2004: 9). ${ }^{4}$ In the process, the POW narrative took its place within the broader cinematic rehabilitation of the war, a process of nostalgic reconstruction that reinstated as heroic a virile middle-class English masculinity 
that the group hero and community emphasis of the war years had rendered regressive and redundant. ${ }^{5}$ By the mid-1950s, argues Richards, the war was being recreated as a 'celebration of the officer class' (1997: 144); Geraghty agrees, noting the emergence of a discourse of 'natural superiority' that renders the officer hero 'impervious' (2000: 188, 190). As I have described elsewhere, in the cinema of 'nostalgic virility' wartime crisis is rewritten as adventure, and national pride is reinstated not through policy or international power, but through the quality of the country's masculinity (Plain, 2006: 141-142).

Yet, as this survey of shifting structures of feeling suggests, arriving at the resurgent English hero was a far from straightforward process. This figure had to be rebuilt from a context in which wartime masculinities were no longer welcome and the returning soldier was perceived as a threat to social stability. This is evident from Alan Allport's recent study of postwar dislocation, which provides a series of disturbing examples both of failures of adjustment and the scarcity of resources available to help returning servicemen. Not even the Civil Resettlement Units (CRUs), designed to offer a 'bridge between prison and civilian life' (2009: 203), felt able publically to acknowledge the mentally and physically destructive nature of long-term captivity, and their advertisements 'scrupulously avoided any mention of psychological counselling' (2009: 203). Yet Allport indicates that the problems of postwar readjustment experienced by POWs were far from unusual; rather they were part of a spectrum of disabling conditions inhibiting the social reintegration of ex-combatants. Men returning from war were variously traumatized - suffering nightmares, paranoia, anxiety - and bored, experiencing the frustration of unemployment or the return to humdrum existences far 
removed from the addictive dangers of wartime. It did not take long before returning servicemen were perceived less as heroes than as social liabilities: unstable, criminal, and possibly 'permanently reprogrammed' into killers (2009: 173, 158-185). In this context the narrative of constraint embodied by POW experience unexpectedly provides a valuable text for negotiating the traumas of postwar masculinity, and it is useful to examine the differences that divide films often loosely clustered together as a subset of the war genre. If The Colditz Story is seen as an end point, rather than a beginning, and if the POW story is recognized as a hybrid genre, it becomes possible to ask new questions of films such as The Captive Heart and the Wooden Horse. The narrative of captivity is one that always threatens to emasculate rather than enable the male hero, and the process of telling such stories in a patriarchal society will inevitably be culturally sensitive. Consequently, the insertion of the POW story into the generic framework of romance, or the postwar 'spiv' cycle of more-or-less noir crime films, indicates the limits of narrative possibility in the postwar years. Some stories could not yet be told, and those that were told worked energetically to police and (re)construct the unstable postwar masculine subject.

\footnotetext{
'A little piece of England': Replicating the national community in The Captive Heart As Charles Barr has noted in his history of the studio, The Captive Heart is in many ways a typical Ealing film. Directed by Basil Dearden, it draws extensively on the conventions of documentary realism to present a group hero, comprised of a representative selection of nationally varied, cross-class characters, embedded within a fundamentally moral and holistic community. The film's typically 'Ealing' qualities are equally evident in its
} 
desire for authenticity. The co-author of the script, Guy Morgan, had himself been a POW, and his memoir Only Ghosts Can Live (1945) reveals the basis for most of the film's events (Burton \& O’Sullivan, 2009: 79). Yet The Captive Heart is also, significantly, a romance - a genre for which Ealing was not so noted: as the critic Kenneth Tynan observed, ‘[Michael] Balcon [the film's producer] has never made a film which paid any real attention to sex. His favourite productions ... deal exclusively with men at work, men engrossed in a crisis, men who communicate with their women mainly by post-card' (Tynan 1955, quoted in Barr 1998: 77). The POW camp, then, is the perfect setting for romance, Ealing style: the central love affair between a Czech officer and the estranged wife of the English soldier whose identity he has assumed to save himself from the Nazis is formulated as an epistolatory fiction. While not the sort of costume melodrama made so popular by Gainsborough studios in this period, this device nonetheless has a self-conscious archaism that is both intimate and distanced. ${ }^{6}$ Like the world of Jane Austen, where the limits of expression are rigidly policed by propriety, Ealing's concept of romance proceeds through the stately exchange of letters in which each writes to the other as though they were strangers. For obvious reasons, this is also a dialogue between male experience and female innocence: while Hasek (Michael Redgrave) knows exactly what he's doing, Celia (Rachel Kempson) writes in a willing suspension of disbelief, fantasising that her boorish husband has miraculously been reborn through the experience of war and captivity.

The epistolatory device also functions to articulate the broader purpose of the film, which is dedicated to the 'unbroken spirit' of British POWs. Over an extended 
montage of community building in which men are seen tending gardens, making music, boxing, betting, lecturing and dressing up in drag, the voice of Michael Redgrave is heard telling Celia of men 'emerging from the twilight ... creating in miniature a world of their own. ... Men who no longer lie down to fate, but face it and find their own ways of beating it.' The debt to wartime cinema is immediately evident here in the portrait of unity in adversity, the community in all its diversity representing in microcosm the wider communion of the nation. The Captive Heart also draws on the structures of feeling mobilised by wartime dramas such as In Which We Serve (1942). It offers multiple points of identification and narratives that cross the divides of class and region. Alongside the story of Hasek's escape from the Nazis, the film follows the stories of 'sensitive' composer Stephen who has come straight from a whirlwind romance to imprisonment; young Scottish lieutenant David Lennox, blinded by his wounds; and the lower-middle class pairing of Londoner Ted Horsfall (Jack Warner) and Welshman Dai Evans (Meredith Evans), who will 'adopt' a delinquent child, Private Mathews (Jimmy Handley), and oversee his community rehabilitation. The triumvirate of Horsfall, Evans and Mathews provide much of the banter essential to group cohesion but they are not simply comic relief. In a re-enactment of the moving exchange from the earlier film in which Shorty Blake tells Walter Hardy that his wife has been killed in the Blitz, Ted receives a letter telling of Dai's wife's death. As was the case with Hardy, Dai's reaction is an exemplary demonstration of stoic dignity.

In its construction of community, then, The Captive Heart draws on the conventions of documentary realism and what Andrew Higson terms the 'melodrama of 
everyday life' (1995: 262). ${ }^{7}$ Although there is no significant crisis in the Hasek/Celia relationship, conventional romantic narratives are provided in the stories of David's blindness and Stephen's overly intense love for his new bride Caroline. Here, the obstacles to romantic resolution are exacerbated by the POW's lack of agency. Stephen can only seethe, play the piano and write a nasty letter after a jealous friend tells him his wife is betraying him, while David, with even less agency, dictates a Dear Jane letter to his fiancée, choosing to tell her he no longer loves her, rather than confessing the emasculating threat of his blindness. These moments take up little screen time, and indicate that the real romantic crisis of The Captive Heart is a group one: individual psychic battles are subordinate to the survival of the group, and the voice of the group is Hasek's letters. The threat to the romance of captivity is that the men will lose their spirit - the spirit celebrated in the opening voice over, and threatened by the awful indefiniteness of their captivity. As Hasek writes in November 1942: 'Deep down in the hearts of all of us dwells a lonely ache, a desperate yearning for those we love, and a fear, a fear of becoming forgotten men.' The group enables the individual to survive, overseeing the physical rehabilitation of David, the psychic rehabilitation of Stephen, the protection of Hasek, and the adoption of Mathews, and the group in turn represents a larger body, one half of a divided nation, a symbolic body uncertain of its romantic reconciliation with home.

The Captive Heart, then, works hard to reassure, while still attempting to acknowledge that reintegration will not be straightforward. So, on the one hand, the narrative offers obvious comfort: Mathews, the professional burglar, is not made by war, 
but rather unmade, redeemed by exposure to the healthy community in exile. On the other hand, the return of Ted and Dai hints that men coming home will bear invisible wounds: entering their street, Ted asks Dai 'how do you feel?', to which Dai can only reply, 'Empty, empty inside'. Thus, in the message of Hasek's letters and the positive reunion scenes that end the film, The Captive Heart makes explicit its attempt to address the fractured society of 1945, and the fears of men and women that returning partners would be physically, socially or psychically unrecognisable (Celia Mitchell unwittingly stands in front of her 'husband' at the dock).

It matters, then, that in 1946, the POW story is configured as romance, as it enables the paradigm of incarceration to carry a broader message of reassurance, and to preach a doctrine of patience and forgiveness. The relationship narratives that form the group romance together encapsulate the fears of postwar readjustment. Dai has to grieve for his wife and meet his four-year old daughter; Stephen must forgive Caroline's affair, and she forgive his lack of trust; David needs to face the fact that, as a wounded veteran, he's going to be silenced. He stands stock still as Elspeth drapes herself over him, and they are reconciled. This is perhaps the most uncomfortable of the reconciliations: while Stephen and Caroline look like conventional melodramatic lovers, and the intimacy and warmth of the relationships between Ted, Dai and Flo ensure that the lower-class reunion is genuinely touching, David, by contrast, seems hopelessly infantilised. Gordon Jackson, in the role, reprises his performance as an inarticulate flight sergeant from Millions Like Us (1943). Although he is comically unable to find the words to propose to Elspeth as he leaves for war, in the male group he finds a voice, confidently acting as storyteller as he 
reads Shakespeare in braille. This agency, however, is undercut by the extreme stillness of his performance and by the fact that the other characters speak to him as if he were a child. We never see him engaging in banter: instead he is always trying to say (and being cut off from actually saying) how grateful he is for the kindness of the group.

The representation of David Lennox gives some indication of how difficult the cinema would find the representation of wounded masculinity, but in terms of the romantic resolution provided by the film, he too is reintegrated into the community with remarkable dispatch. The film, then, works overtime to reinforce its central message, which is put into words by Celia's description of village life: 'Everything's changed, and yet nothing's changed'.

\section{Build Your Own Tunnel: The Wooden Horse and escape noir}

The ease with which The Captive Heart reintegrated prisoners into the community and domesticity of home gives some indication of just how much anxiety surrounded the processes of demobilisation and repatriation. As indicated above, one of the great fears of postwar society was that men would return unable to integrate into society, bringing lawlessness and disorder with them (Allport, 2009: 163-65; Hately-Broad, 2009: 229232). ${ }^{8}$ This anxiety found its generic form in the disaffected ex-servicemen and damaged communities of the 'spiv' cycle, and in the emergence of these sub-cultural forces and criminal desires we see one of the 'volatile' shifts in structures of feeling identified by Harper and Porter. The operation of these shifts is equally evident in the genesis of The Wooden Horse (1950). The book's author Eric Williams had enjoyed success in 1945 
with a short account of POW life, Goon In The Block, and once the war was over, had sought to capitalise on this with a longer account of his own escape from Germany. However, by the time his 200,000-word manuscript was ready, no one wanted to read about the war, and seven publishers followed Cape's lead in rejecting the book. Yet when The Wooden Horse was eventually published in 1949, it became an instant success. ${ }^{9}$ The precise reasons for this are hard to determine, but might be attributed to a shift in popular mood akin to that which underpinned the resurgence of war cinema, or to Williams' decision to fictionalise his autobiography, a strategy which permits a more revealing account of the tensions that shape the experience of captivity. In Williams' work, hostility and resentment are brought vividly to life:

From the corner on his right hand came the mumbled ends of Robbie's morning hymn of hate $[\ldots]$ 'Christ, what a noisy mucker that fellow Bennett is.' There was bitterness in it, and finality. They would quarrel soon, Peter could see it coming. Starting over some small detail it would flare up into a violent feud. ... It was like that in the prison camp. A man could stand the boredom for so long and then, slightly at first, the personal habits of one of his seven companions would begin to wear him down. Little things such as the way the man ate, or possibly his accent. Life with him would become unbearable (Williams, 1949: 15).

It is not that the homosocial bond has broken down, but rather that it has regressed. The claustrophobia of prison society puts all relationships under pressure, and significantly, the camp threatens to enact a feminising process, depriving men of the 
agency and self-control integral to masculine self-fashioning. In this context, The Wooden Horse draws on the generic features of the spiv cycle, depicting a noir environment in which a man - used to freedom and choice - can feel bored and embittered, pushed to the edge of self-destruction by the unbearable constraints of existing outside the war. The community that seemed so nurturing in The Captive Heart is here depicted as stifling and oppressive. The prison camp is a bare space, an anti-home: all effort and ingenuity are directed towards escape and reclaiming agency. In The Wooden Horse tunnelling, like crime, becomes an illicit activity restoring masculinity through danger, but - unlike the films of the spiv cycle - the context of war enables this illegality to be reconfigured as honest toil. The film is thus able not only to represent postwar anxieties about a spectrum of male pathologies, from the seasoned disaffection of redundant ex-servicemen to the emergent force of 'delinquent' youth cultures, but also to offer solutions to these problems through alternative narratives of man making.

It has already been noted that the British war film underwent a significant ideological transformation in the postwar period, and these films also generated a not insignificant change in the representation of 'British male endeavour and the national character' (Spicer, 2001: 35). At the heart of the cycle of war films that began in the early 1950s resided a male bond most frequently configured through the relationship between an older and a younger man: the stern father figure and what Raymond Durgnat labelled the 'eternal cadet' (2011: 174). This, according to Andrew Spicer, represented an antidote to criminal masculinities: 
In a society that $\ldots$ had become preoccupied with the disaffected working-class young man (the 'delinquent'), the cadet was being offered, by a number of British producers, as the responsible figure of young manhood with whom male adolescents should identify (Spicer, 2001: 38).

The Wooden Horse, typically for the unstable generic form of the POW film, conforms in part, but it also opens up another less hierarchical, but no less homosocial, space for the reconfiguration of masculinity: homoerotic adolescence. The film narrows the broad focus seen in The Captive Heart to emphasise the bond between men and dwells extensively on the spectacular body of the prisoner. In a camp that feels more like a borstal than a public school, the constraints - and the threat - of confinement are countered by an intense focus on the athletic male body. Women are almost entirely absent and play no emotional role: they do not even function as significant memories. Rather we see the reassertion of a signifying physicality in the construction of male identity. Visually, The Wooden Horse is dominated by half-naked men who vault horses and dig tunnels - a process that absorbs at least two thirds of the narrative. Within this energetic frame, the central characters - Flight Lieutenant Peter Howard (Leo Genn) and Captain John Clinton (Anthony Steel) - simultaneously enact and undermine the fathercadet relationship. Peter is older, a calm, patient figure who turns John's ideas into practical, workable plans. John, referred to as the 'child' by others in the hut, is more impetuous. In the camp he is the student who cannot wake up and is always lost in a book; once the escape is underway he is the one proposing action, while Peter cautions the need to talk to people, an irony not lost on John, since he - as the only linguist - must 
do the talking. This balance of skills defuses the hierarchy implicit in Peter's age, and turns their relationship into an early manifestation of the mismatched 'buddy' couple.

The conditions, then, are those of the intimate friendships and signifying activities of a more mature boyhood. The Germans, who feature little, are the distant parent figures, and life in the prison has the bare qualities of a scout camp. Different groups of boys hang out together - there are no gardens or pet rabbits - and the atmosphere in the hut is more febrile. Men take sides and when the fastidious Pomfret complains that John is neglecting his mess duties, he is inevitably feminized. The only one in the hut to be wearing clean, tidy RAF battledress, in complaint Pomfret's voice rises sharply to the edge of hysteria. Pomfret's feminization embodies the threat of arrested development inherent in prolonged incarceration: camp life inhibits the necessary maturation of boys into men. When Peter is asked why he wants to escape, he voices a fear that life is passing him by and a desire for quotidian agency: 'to do the ordinary things again ... spend money and have to make a decision.' Implicit here is the familiar association of masculinity with agency, a connection that in turn sees the Senior British Officer in The Colditz Story described as an 'old woman' when he is mistakenly thought to have no interest in escaping. In The Wooden Horse, then, a man is made through work, understood not as the feminine necessity of making lunch for the mess, but as the physical labour of tunnelling and the engineering skills that enable the project. The film, like the book before it, provides lavish detail on how the tunnel was constructed. We see Peter sketch the book's diagrams, while other actors offer a practical demonstration of the logistics of digging, earth removal and gymnastics. What is being celebrated in this story 
is not endurance, as in The Captive Heart, nor the legendary, superheroic subversions of Colditz, but rather the practical virtues of conventional artisan masculinity. This emergent emphasis is evident in a comparison of similar scenes. In The Captive Heart three men must leave the security of the hut at night to break into the camp office and alter paperwork so that Hasek can escape. The sequence is tense, the Germans a significant threat, as is clear when one of the men is savaged by a dog. In The Wooden Horse two men leave the hut to break into a construction site in search of wood for the horse. The sequence is short and intercut with shots of men distracting the guard dogs - a ploy that works without a hitch. The most emphatic camera shot is a lingering close-up of a trowel, found serendipitously in the half-constructed shed. For the bulk of the film, then, jeopardy is less of an issue than the technical difficulties of building, and danger lies not with the Germans but with the risk of industrial accident, as is demonstrated when the tunnel collapses on Peter.

The film's emphasis on work and its celebration of the virtues of traditional masculine labour have seen it, like The Captive Heart, aligned with the 'visual tropes of documentary realism' (Harper \& Porter, 2003: 253). However, its singular narrative focus, and its presentation of the camp - in part at least - as a bleak subculture rather than a wholesome community, suggests it too is a hybrid generic product. Offering unparalleled detail on how to dig your way out of a POW camp, The Wooden Horse can be seen both to metaphorize the frustrations of postwar masculinity and to celebrate - and redirect attention towards - the construction of masculinity through conventional (nonmilitary) modes of work. Boys become men through asserting a distance from the 
feminine, and in The Wooden Horse Peter and John demonstrate that this can reliably be achieved through the traditional - and socially reassuring - virtues of DIY.

\section{Conclusions}

Lying in his bunk in The Captive Heart, Hasek writes to Celia that afterwards, 'in our memories, we shall relive only the sunny days, the pleasant scenes, the freedom of mind and the comradeship', an anticipation of nostalgia borne out by Allport's observations regarding veterans' changing relationship with the armed forces (2009: 217). It is also borne out by the choices made in filming The Colditz Story. Here, British cinema melds the two most popular genres of the period, comedy and war, to turn incarceration into a story of adventure played out in the manner of an energetic school farce. Earlier manifestations of POW narratives tell a different story, and the differences in the telling in turn expose the shifting priorities and anxieties of the postwar period. In 1946 the prison camp was allowed to be a feminised space, and making it so is a strategy of reassurance in relation to immediate postwar fears of violent, pathologized masculinity. In 1950 the domesticity of camp life, while unwelcome, becomes an acceptable mode of masculinity through its presentation as a different sort of camping: that undertaken by boy scouts roughing it in the woods. More crucially, the concern with technologies of escape turns the film into a 'Boys Own Book of Knowledge', providing the diagrams, mathematics and logistics to build your own tunnel. Women appear only as silent assistants to male agency, or as the successful escaper's reward, and it is significant that we do not see the heroes of The Wooden Horse rejoin their units, as the opening credits suggest should be their aim. Rather the film ends with the escapers liberated not into the 
enclosing space of 'home' but into an imagined utopia of laden tables, dance bands and Scandinavian beauties. The absence of home from this story is a sign of things to come: as the 1950s progressed, the home front would be written out of the narrative of war, and the home itself reconfigured as a space of confinement and constraint, presided over by such pathological or infantile women as Morrel's wife in The Cruel Sea (1953) and Holden's in Dunkirk (1958). As a result, these films trace a transformation from an idealization of home rooted in a wartime ideology of the national community, to a denial of home and a valorization of the male agent as a figure of constant, purposeful motion. By ending with its escapers in 'neutral' territory, The Wooden Horse avoids the difficulties of reintegration, and affirms that home and heroism are no longer to be conflated.

One thing that unites The Captive Heart and The Wooden Horse, however, is the difficulty of articulating the psychological damage of imprisonment. The Captive Heart comes closer, but it gives the expression of emotion to an outsider, a Czech professor of English, who is in any case writing words that cannot be spoken. Consequently, the film's acknowledgement of the emasculating force of boredom and inactivity is reassuringly accompanied by the spectacle of the British POW making his own entertainment, creating a society in microcosm that will enable masculinity to be reinstated through the conventional forms of work and sport. In The Wooden Horse we see the same reassurance configured through individual agency: the determination of two 'typical' men to defy the odds and enact the triumph of the underdog. Five years' later, these representations would in turn be overwritten by the Colditz myth: 'the dominance 
of a particular set of images of British prisoner life in Germany within the collective imagination, in which high spirits and escape attempts are constant factors' (MacKenzie, 2004: 25). The impossibility of escape becomes the duty of escape, becomes the pleasure of escape; or, in generic terms, romance, becomes noir, becomes something approximating comedy. ${ }^{10}$ In all cases, however, the representation of the POW extends beyond verisimilitude, and can be seen to symbolize the problems of a postwar world in which many struggled to readjust, and society energetically sought new narratives through which to imagine heroic male agency.

\section{Bibliography}

Allport, Alan. 2009. Demobbed: Coming Home After the Second World War. New Haven: Yale University Press.

Babington, Bruce. 2002. Launder and Gilliat. Manchester: Manchester University Press. Barr, Charles. 1998 [1977]. Ealing Studios. Moffat: Cameron \& Hollis.

Burton, Alan \& O’Sullivan, Tim. 2009. The Cinema of Basil Dearden and Michael Relph. Edinburgh: Edinburgh University Press.

Durgnat, Raymond. 2011 [1970]. A Mirror for England: British Movies from Austerity to Affluence. London: BFI.

Ellis, John.1996. The Quality Film Adventure: British Critics and the Cinema 1942-1948. In: Andrew Higson, ed. Dissolving Views: Key Writings on British Cinema. London: Cassell, pp. 66-93.

Geraghty, Christine. 2000. British Cinema in the Fifties: Gender, Genre and the 'New Look’. London: Routledge. 
Gilbert, Adrian. 2006. POW: Allied Prisoners in Europe, 1939-1945. London: John Murray.

Harper, Sue \& Vincent Porter. 2003. British Cinema of the 1950s: The Decline of Deference. Oxford: Oxford University Press.

Hately-Broad, Barbara. 2009. War and Welfare: British Prisoner of War Families, 193945. Manchester: Manchester University Press.

Higson, Andrew. 1995. Waving the Flag: Constructing a National Cinema in Britain. Oxford: Clarendon Press.

Kynaston, David. 2007. Austerity Britain, 1945-51. London: Bloomsbury.

Landy, Marcia. 1991. British Genres: Cinema and Society, 1930-1960. Princeton, NJ: Princeton University Press.

Light, Alison. 1991. Forever England: Femininity, Literature and Conservatism Between the Wars. London: Routledge.

MacKenzie, S. P. 2004. The Colditz Myth: British and Commonwealth Prisoners of War in Nazi Germany. Oxford: Oxford University Press.

Morgan, Guy. 1945. Only Ghosts Can Live. London: Crosby Lockwood.

Murphy, Robert. 2000. British Cinema and the Second World War. London: Continuum.

Paris, Michael ed. 2007. Repicturing the Second World War: Representations in Film and Television. London: Palgrave.

Plain, Gill. 2006. John Mills and British Cinema: Masculinity, Identity and Nation. Edinburgh: Edinburgh University Press.

Plain, Gill. 2013. Literature of the 1940s: War, Postwar and 'Peace'. Edinburgh: Edinburgh University Press. 
Rattigan, Neil. 1994. The last gasp of the middle class: British war films of the 1950s. In: Wheeler Winston Dixon ed. Re-Viewing British Cinema, 1900-1992. Albany, NY: State University of New York Press, pp. 143-153.

Reid, P. R. 2001 [1952]. The Colditz Story. London: Cassell.

Reid, P. R. 2003 [1953]. The Latter Days at Colditz. London: Cassell.

Richards, Jeffrey. 1997. British Films and National Identity: From Dickens to Dad's Army. Manchester: Manchester University Press.

Rolf, David. 1988 [1989]. Prisoners of the Reich: Germany's Captives 1939-1945. London: Coronet.

Segal, Lynne. 1997 [1990]. Slow Motion: Changing Masculinities, Changing Men. London: Virago.

Spicer, Andrew. 2001. Typical Men: The Representation of Masculinity in Popular British Cinema. London: I. B. Tauris.

Williams, Eric. 1949. The Wooden Horse. London: Collins.

Worpole, Ken. 1983. Dockers and Detectives, Popular Reading: Popular Writing. London: Verso.

\footnotetext{
${ }^{1}$ For some, the activity of escape planning served as an end in itself. It became a performance of agency never destined to be enacted, and functioned much like self-improvement activities, entertainment and reading. See Gilbert, 2006: 266.

${ }^{2}$ William Watkin notes that 'emotion is primarily a social construct' (2004: 50), and in a culture that valorized euphemism, restraint and understatement, the language of complaint in mid-century Britain was profoundly limited. See Plain, 2013: 179.

${ }^{3}$ Reid does not deny the psychological reality of imprisonment; rather the subject is contained through brevity and understatement, as is indicated by the succinct assertion that 'the majority of the men who
} 
sought to escape did it for self-preservation ... they felt that resignation meant not physical but mental death - maybe lunacy' (1951/2001: 38). The Latter Days at Colditz (1953) also seeks to defuse the implications of mental breakdown, speculating that the proportionately large number of men who became 'unbalanced' was not a sign of an inability to cope, but rather attributable to the 'atmosphere' of Colditz, which had previously been used as a lunatic asylum (2003: 102).

${ }^{4}$ Significantly, one of most successful films of the previous year had been the anarchic comedy The Belles of St Trinians (1954).

${ }^{5}$ I use 'English' advisedly. A key feature of 1950s nostalgic virility was the effacement of class, regional and national difference from constructions of heroism.

${ }^{6}$ And, like the Gainsborough melodramas, this aspect of the film was dismissed as 'melodramatic' (Burton \& O'Sullivan, 2009: 81). Yet, as Burton and O'Sullivan observe, letters were integral to POW experience, and to imagine that men in captivity did not experience dark fantasies and imaginings, indicates the extent to which reviewers of the time valorized a middle-class realist aesthetic (Ellis, 1996: 79).

${ }^{7}$ Higson defines this as 'the incorporation of certain features of the documentary idea into the conventions of the domestic melodrama to produce a brand of fiction film which purports to deal realistically with life in contemporary Britain' (1995: 262). His examples are Millions Like Us (1943) and This Happy Breed (1944).

${ }^{8}$ Allport's conclusions are supported by the preoccupations of popular fiction in the period. Novels such as Nigel Balchin's Mine Own Executioner (1945) and Hammond Innes's Air Bridge (1951) are two of the many texts to suggest that ex-combatants might be damaged and dangerous figures. See Stewart, 2006: 153-60 and Plain, 2013:188-96.

${ }^{9}$ The success of the book is evident from the number of reprints. A children's version appeared in 1956, and a thirtieth-anniversary revision was published in 1978.

${ }^{10}$ This is not to suggest that The Colditz Story makes light of all aspects of escaping. The virtual suicide of Mac, in particular, creates a tension which the narrative struggles to resolve. 